\title{
Kan depresjon reduseres hos pasienter som får dialyse?
}

Kognitiv atferdsterapi, rådgivning, trening og avspenningsteknikker reduserer trolig symptomene på depresjon sammenliknet med vanlig praksis.

Therese Kristine Dalsbø

Seniorrådgiver

Område for helsetjenester, Folkehelseinstituttet

Mirjam Lauritzen

Prosjektleder

Samvalgssenteret, Universitetssykehuset Nord-Norge

Dialyse

Depresjon

Sykepleien Forskning 202015 (81618) (e-81618)

DOI: 10.4220/Sykepleienf.2020.81618

Det viser en Cochrane-oversikt. Med vanlig praksis

menes dialysebehandling gitt på vanlig måte.

\section{Hva sier forskningen?}

I systematiske oversikter samles og vurderes tilgjengelig forskning. I denne systematiske Cochrane-oversikten var spørsmålet dette: «Hva er effekten av psykososiale tiltak hos personer som får dialyse sammenliknet med vanlig praksis?».

Resultatene viser følgende:

- Kognitiv atferdsterapi reduserer trolig symptomene på depresjon sammenliknet med vanlig praksis. 
- Rådgivning reduserer muligens symptomene på depresjon

litt sammenliknet med vanlig praksis.

- Trening reduserer trolig symptomene på depresjon sammenliknet med vanlig praksis.

- Avspenningsteknikker reduserer trolig symptomene på depresjon sammenliknet med vanlig praksis.

\begin{tabular}{|c|c|c|c|}
\hline Hva skjer? & Vanlig praksis & MED tiltak & $\begin{array}{l}\text { Tillit til } \\
\text { resultatet }^{1}\end{array}$ \\
\hline \multicolumn{4}{|c|}{ Effekt av kognitiv atferdsterapi sammenliknet med vanlig praksis } \\
\hline $\begin{array}{l}\text { Kognitiv atferdsterapi reduserer trolig symptomene på } \\
\text { depresjon sammenliknet med vanlig praksis }\end{array}$ & $\begin{array}{l}21,39 \\
\text { Poeng på en } \\
\text { depresjonsskala }\end{array}$ & $\begin{array}{l}\text { 6,1 poeng lavere } \\
(-8,63 \text { til }-3,57)^{*}\end{array}$ & $\begin{array}{l}\oplus \oplus \oplus \bigcirc \\
\text { Middels }\end{array}$ \\
\hline \multicolumn{4}{|l|}{ Effekt av rådgivning sammenliknet med vanlig praksis } \\
\hline $\begin{array}{l}\text { Rådgivning reduserer muligens litt symptomene på } \\
\text { depresjon sammenliknet med vanlig praksis }\end{array}$ & $\begin{array}{l}\text { 18,54 } \\
\text { Poeng på en } \\
\text { depresjonsskala }\end{array}$ & $\begin{array}{c}\text { 3,84 poeng lavere } \\
(-8,63 \text { til }-3,57)^{*}\end{array}$ & $\begin{array}{l}\oplus \oplus \bigcirc \bigcirc \\
\text { Liten }\end{array}$ \\
\hline \multicolumn{4}{|l|}{ Effekt av trening sammenliknet med vanlig praksis } \\
\hline $\begin{array}{l}\text { Trening reduserer trolig symptomene på depresjon } \\
\text { sammenliknet med vanlig praksis }\end{array}$ & $\begin{array}{l}\text { 22,1 } \\
\text { Poeng på en } \\
\text { depresjonsskala }\end{array}$ & $\begin{array}{l}\text { 7,61 poeng lavere } \\
(-9,59 \text { til }-5,63)^{*}\end{array}$ & $\begin{array}{l}\oplus \oplus \oplus \bigcirc \\
\text { Middels }\end{array}$ \\
\hline \multicolumn{4}{|c|}{ Effekt av avspenningsteknikker sammenliknet med vanlig praksis } \\
\hline $\begin{array}{l}\text { Avspenningsteknikker reduserer trolig symptomene på } \\
\text { depresjon sammenliknet med vanlig praksis }\end{array}$ & $\begin{array}{l}\text { 30,83 } \\
\text { Poeng på en } \\
\text { depresjonsskala }\end{array}$ & $\begin{array}{l}5,77 \text { poeng lavere } \\
(-8,76 \text { til }-2,78)^{*}\end{array}$ & $\begin{array}{l}\oplus \oplus \oplus \bigcirc \\
\text { Middels }\end{array}$ \\
\hline \multicolumn{4}{|c|}{ 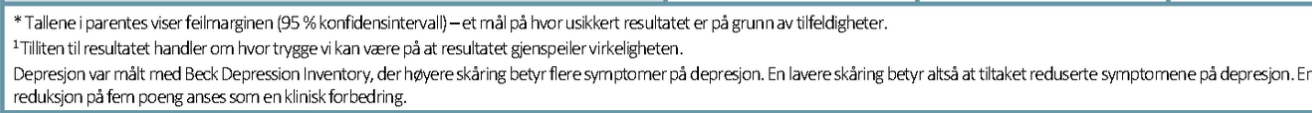 } \\
\hline
\end{tabular}

\section{Bakgrunn}

Pasienter som får dialysebehandling, har $\varnothing \mathrm{kt}$ risiko for depresjon. Behandling med hemodialyse kan gjøres på sykehus, ved enkelte helsesentre eller hjemme.

De fleste har behov for dialysebehandling annenhverdag i fire-fem timer, men dette er individuelt. I tillegg til dialysen tar det noe tid å kople til og fra dialysemaskinen samt å reise til og fra behandlingsstedet (kilde: Hemodialyse).

Det kan være så mange som en av fire som får depresjon underveis i behandlingen. For pasientene som får depresjon, kan livskvaliteten reduseres, og det reduserer sjansen for å nå behandlingsmålene. Psykososiale tiltak har ulike innretninger, men felles er at de gir støtte enten psykologisk, følelsesmessig eller sosialt. 
Slike tiltak kan gis i gruppe eller enkeltvis og kan vare over kort eller lang tid. Noen tiltak følger et strukturert behandlingsopplegg. Formålet er å redusere sykdomsbyrden, $\varnothing$ ke mestringsfølelsen og håndtere stress og frykt.

\section{Hva er denne informasjonen basert på?}

Forfatterne av Cochrane-oversikten gjorde i juni 2019 et s $\varnothing \mathrm{k}$ i det sentrale studieregisteret til Cochrane. Dette registeret fanger opp referanser til kontrollerte effektstudier fra en rekke forskningsdatabaser. De fant 33 randomiserte og kvasirandomiserte kontrollerte studier med til sammen 2056 pasienter.

Det var resultater fra 26 av studiene som kunne brukes i metaanalyser. De fant til sammen 16 ulike sammenlikninger. Siden det da ble svært få studier og få pasienter med i hver av sammenlikningene, ble tilliten til resultatene middels og liten.

Pasientene som var med i studiene, gikk til dialysebehandling, men noen av dem hadde også en depresjonsdiagnose. Det ble også funnet referanser til sju pågående studier. 


\begin{tabular}{|c|c|c|}
\hline $\mathrm{PICO}$ & Hva lette de etter? & Hva fant de? \\
\hline Populasjon & Alle personer i dialysebehandling & $\begin{array}{l}\text { Pasientene som gikk til dialysebehandling hadde kronisk } \\
\text { nyresykdom i endestadiet. Noen av pasientene hadde allerede } \\
\text { depresjon, mens andre fikk forebyggende tiltak for ikke å få } \\
\text { depresjon. Alle pasientene fikk hemodialyse }\end{array}$ \\
\hline $\begin{array}{l}\text { Tiltak og } \\
\text { sammenlikning }\end{array}$ & $\begin{array}{l}\text { Alle tiltak som enten var ment å } \\
\text { forebygge eller behandle } \\
\text { depresjon, var relevante. } \\
\text { Relevante tiltak var psykososiale } \\
\text { tiltak, trening eller rådgivning } \\
\text { sammenliknet med standard } \\
\text { praksis eller en annen psykososial } \\
\text { intervensjon. Legemidler og } \\
\text { elektrosjokkbehandling var ikke } \\
\text { relevant. }\end{array}$ & $\begin{array}{l}\text { De fant forskning hovedsakelig om standard praksis } \\
\text { sammenliknet med følgende tiltak: } \\
\text { - } \text { akupunktur } \\
\text { - } \text { kognitiv atferdsterapi } \\
\text { - rådgivning } \\
\text { - } \text { opplæring } \\
\text { - } \text { trening } \\
\text { - } \text { meditasjon } \\
\text { - } \text { avspenning } \\
\text { - } \text { religiøs støtte } \\
\text { - } \text { telefonsial aktivitet } \\
\text { Tiltakene ble hovedsakelig gitt av enten en sykepleier eller en } \\
\text { psykolog. }\end{array}$ \\
\hline Utfall & $\begin{array}{l}\text { Deres primærutfall var depresjon } \\
\text { og helserelatert livskvalitet. } \\
\text { Sekundærutfall var angst, kognitiv } \\
\text { funksjon, sykehusinnleggelse, } \\
\text { død, selvmordsfors } \varnothing \text {, } \\
\text { opprettholdelse eller frafall av } \\
\text { dialysebehandling og uønskede } \\
\text { hendelser }\end{array}$ & $\begin{array}{l}\text { Vi har bare omtalt utfallet om depresjon for fire av } \\
\text { hovedsammenlikningene. Depresjon var målt med Beck } \\
\text { Depression Inventory (BDI). Oppfølgingstiden var } \\
\text { gjennomgående ganske kort, stort sett ikke lenger enn fire } \\
\text { måneder. BDI har } 21 \text { spørsmål som kan besvares på en } \\
\text { firepunktsskala fra null til tre, og der samlet skåring kan svare på } \\
\text { hvor deprimert pasienten er. Jo høyere skåring, desto mer } \\
\text { symptomer på depresjon. Skåringene fra 0-13: minimal } \\
\text { depresjon, 14-19: mild depresjon, 20-28: moderat depresjon, } \\
\text { 29-63: alvorlig depresjon. En reduksjon på fem poeng anses } \\
\text { som en klinisk forbedring. }\end{array}$ \\
\hline Setting & Hvor var studiene utført? & $\begin{array}{l}\text { Studiene var utført i } 15 \text { land. De fleste studiene var utført i USA } \\
\text { (8), Iran (5), Singapore (3), England (3), Hellas (3), Polen (3) og en } \\
\text { studie fra henholdsvis Brasil, Canada, Indonesia, Jordan, } \\
\text { Malaysia, Mexico, Singapore, Taiwan, Tunisia og Tyrkia. }\end{array}$ \\
\hline $\begin{array}{l}\text { Tillit til } \\
\text { resultatet }\end{array}$ & $\begin{array}{l}\text { Oversiktsforfatterne laget fem } \\
\text { resultattabeller for } \\
\text { hovedsammenlikningene ved } \\
\text { hjelp av GRADE }\end{array}$ & $\begin{array}{l}\text { Fordi studiene ikke er gjennomf } \varnothing \text { rt godt nok, og fordi studiene } \\
\text { ikke er store nok, er tilliten jevnt over trukket ned fra høy til } \\
\text { middels, liten og svært liten. }\end{array}$ \\
\hline
\end{tabular}

\section{Systematisk oversikt}

I systematiske oversikter søker man etter og oppsummerer studier som svarer på et konkret forskningsspørsmål. Studiene blir funnet, vurdert og oppsummert ved å bruke en systematisk og forhåndbeskrevet fremgangsmåte (les mer på Cochrane Consumer Network).

\section{Tillit til resultatet (GRADE)}

Når vi oppsummerer studier og presenterer et resultat, er det viktig å si noe om hvor mye tillit vi kan ha til dette. Det handler om hvor trygge vi kan være på at resultatet gjenspeiler virkeligheten. GRADE er et system vi bruker for å kunne bedømme tilliten til resultatet. I GRADE vurderer vi blant annet 
- om studiene er like nok

- hvor relevante studiene er

- om alle relevante studier er fanget opp

\section{Referanse}

Natale P, Palmer SC, Ruospo M, Saglimbene VM, Rabindranath KS, Strippoli GFM. Psychosocial interventions for preventing and treating depression in dialysis patients. Cochrane Database of Systematic Reviews. 2019;(12):art.nr.: CDo04542. DOI: 10.1002/14651858.CDo04542.pub3.

Les hele Cochrane-oversikten her: Psychosocial interventions for preventing and treating depression in dialysis patients 